\title{
Characterization and Evaluation of Pattanam Sheep of Tamilnadu
}

\author{
T. Ravimurugan* and P. Pavithra \\ Department of Animal Genetics and Breeding \\ Veterinary College and Research Institute, Tirunelveli-627358, Tamil Nadu (India) \\ (Tamil Nadu Veterinary and Animal Sciences University) \\ *Corresponding author
}

Ke y w o r d s
$\begin{aligned} & \text { Pattanam breed, } \\ & \text { Sheep, Tamil Nadu }\end{aligned}$
Article Info
$\begin{aligned} & \text { Accepted: } \\ & 20 \text { May } 2020 \\ & \text { Available Online: } \\ & \text { 10 June } 2020\end{aligned}$

\section{A B S T R A C T}

A study on evaluation and morphological characterization of Pattanam and Ramnad White sheep breed, distributed in Ramanathapuram, Pudukottai, Sivagangai, Madurai and Dinigul districts of Tamil Nadu state, was undertaken in the farmers' flocks during the year 2019. The present study shows that the colour, horn pattern and body confirmation are entirely different for both the breeds.Owing to the growing preference among the farmers and larger size of the Pattanam sheep breed it would be advantageous to the farmers if the sheep breed is registered soon. And so, it will be helpful for researchers to enhance genetic improvement in this breed and the economic status of those farmers can be improved.

\section{Introduction}

According to $20^{\text {th }}$ livestock census, the population of sheep in Tamil Nadu is 4.5 million. Tamil Nadu stands $5^{\text {th }}$ in sheep production in India. There are totally 10 registered breeds of sheep in Tamil Nadu. Pattanam, though the breed yet to be registered.

Pattanam breed of sheep accounts for the highest sheep population of southern region of Tamil Nadu. The animals of this breed are very hardy and have good migratory capacity.
The animals are found in Ramanathapuram, Pudukottai, Sivagangai, Madurai and Dinigul districts of Tamil Nadu and are well adapted to erratic and harsh climate conditions of arid and semi-arid region.

Pattanam sheep differs in many aspects as compared to Ramnad white sheep, which is another popular sheep breed distributed in the same tract. The present study is carried out to collect information on Pattanam sheep for registering in the National Bureau of Animal Genetic Resources list of registered sheep breeds. 


\section{Materials and Methods}

A study on evaluation and morphological characterization of Pattanam and Ramnad White sheep breed, distributed in Ramanathapuram, Pudukottai, Sivagangai, Madurai and Dinigul districts of Tamil Nadu state, was undertaken in the farmers' flocks during the year 2019. Information on distribution area, body measurements and population status were collected through personal observations and interaction with the farmers. Such information is helpful for registration of Pattanam breed and its further genetic improvement programme. Microsatellite analysis of Ramnad White and Pattanam were collected from available literatures and mentioned in the article for supportive evidence for the two breeds are separate entities.

\section{Results and Discussion}

\section{Distribution}

Pattanam sheep also known as Pattanathadu or Pullasemari, traces its breeding tract to Paramakudi, Mudukulathur, and Kamuthi taluks of Ramnad districts and Aruppukottai and Thiruchuli taluks of Virudhunagar district of southern agro- climatic zones of Tamil Nadu (Ravimurugan et al., 2012b); while the sheep with original Ramnad White characteristics were found to be sporadically distributed in Aruppukottai and Sivakasi blocks of Virudhunagar district and Vasudevanallur block of Tirunelveli district. The breeding tract had shrunk to a small geographical area and restricted to few villages of three blocks. Still, the purebred flocks of Ramnad White sheep were found to exist in villages like Thuraisamiyapuram and Themalai of Tirunelveli district and Kothukundu and Menmeni of Virudhunagar district. The State Animal Husbandry Department, Tamil Nadu maintains a flock of about 230 Ramnad White sheep under selective breeding at District Livestock farm, Pudukkottai, Tamil Nadu, which is located at outside the home tract (Ravimurugan et al., 2012a)

\section{Breed characteristics}

The Body colour of Pattanam sheep is uniformly creamy white with black colour in the ventral region of jowl extending upto inguinal region. In Ramnad white, coat colour is predominantly milky white in nature. Black rings around the eyes and mouth are typical characteristics of this breed. Further, black patches are seen in switch of the tail, areas of knee, hock and pastern joint (up to hoof) and in tip of preputial sheath of males. The horn pattern differs widely between the two breeds (Ravimurugan, 2017).

In Pattanam rams, horns are large, thick, twisted and highly corrugated; directed backwards, inwards and upwards. In Ramnad white rams, the horn are curled, running backwards and downwards. The horn length also varies as widely as $42.65 \pm 0.15 \mathrm{~cm}$ in Pattanam rams and16-36 cm in Ramnad white rams. In both breeds, ewes are polled. Ears are medium in length and horizontal in Pattanam sheep, whereas it is directed outward and downward in Ramnad white sheep. Pattanam rams have slightly longer hair in the neck and brisket regions.

\section{Body weight and body measurements}

In Pattanam sheep, the mean weight of adult male and female were estimated as $51.50 \pm 1.20 \mathrm{~kg}$ and $36.95 \pm 0.51 \mathrm{~kg}$, respectively. The body length, height and heart girth, paunch girth were obtained as $80.65 \pm 0.49 \mathrm{~cm}, 85.58 \pm 0.58 \mathrm{~cm}, 93.65 \pm 0.35 \mathrm{~cm}$ and $96.35 \pm 0.68 \mathrm{~cm}$, respectively in males and $70.05 \pm 0.45 \mathrm{~cm}, 72.80 \pm 0.65 \mathrm{~cm}, 78.34 \pm 0.35 \mathrm{~cm}$ and $83.87 \pm 0.36 \mathrm{~cm}$, respectively in females. 
Whereas in Ramnad White sheep, the least squares means for body weight, height at withers, body length, heart girth, paunch girth, face length, ear length and tail length were $\quad 31.05 \pm 0.57 \mathrm{~kg}, \quad 74.22 \pm 0.71 \mathrm{~cm}$, $66.82 \pm 0.87 \mathrm{~cm}, 81.65 \pm 0.82 \mathrm{~cm}, 72.43 \pm 1.15 \mathrm{~cm}$, $24.35 \pm 0.74 \mathrm{~cm}, \quad 12.79 \pm 0.28 \mathrm{~cm} \quad$ and $7.84 \pm 0.25 \mathrm{~cm}$, respectively in males and $23.50 \pm 0.27 \mathrm{~kg}, 69.88 \pm 0.33 \mathrm{~cm}, 59.19 \pm 0.41 \mathrm{~cm}$, $73.44 \pm 0.39 \mathrm{~cm}, 69.96 \pm 0.54 \mathrm{~cm}, 18.23 \pm 0.35 \mathrm{~cm}$, $12.27 \pm 0.13 \mathrm{~cm}, 7.81 \pm 0.12 \mathrm{~cm}$, respectively in females (Ravimurugan and Devendran, 2009).

\section{Population}

Total sheep population in surveyed taluks was $2,85,000$. Out of these, about 78.2 per cent were Pattanam sheep. Based on sample survey, the estimated population of Pattanam sheep in its breeding tract is 2,22,870. Population status of Ramnad white sheep according to $18^{\text {th }}$ livestock census (2007) was $15,36,659$ which was the total population. However, the present study reveals that less than 500 breedable females could only be enumerated as pure Ramnad white in their home tract used for breeding. The low male, female ratio associated with long term use of the same ram within the flock may lead to surfacing up the deleterious effect of inbreeding. Therefore, the farmers need to be educated for exchange of the rams between the flocks to circumvent potential harmful effects of inbreeding. By the above mentioned population status, the Pattanam sheep is in sufficient number whereas Ramnad white sheep is in an alarming state. Therefore, it requires high attention for conservation. The government of Tamil Nadu has realised the importance for conservation of indigenous breed of sheep and sanctioned Rs. 80.00 lakhs for conservation of sheep including Ramnad White at southern Tamil Nadu in Veterinary College and Research Institute, Tirunelveli.

\section{Microsatellite analysis}

Ramachandran et al., 2015 observed that a wide range of genetic variation as allele varied from 4 to 12 andthe mean of alleles was7.0in Pattanamsheep breed. The genetic variability in 57 DNA samples of Ramnad white breed was assessed. A Total of 232 alleles were identified across 24 markers. The average estimates of allele diversity (9.667), observed heterozygosity (0.708) and gene diversity (0.759) are studied. Analysis of individual genotypes provided valuable information for understanding intra and interpopulation genetic differences (Raja et al., 2012)

\section{Farmers' preference}

When compared to Ramnad White, Rams of Pattanam sheep is larger in size which seems eye catching to the farmers, so they purchase and use them for breeding in their flock. Moreover, because of its large size, the lambs attain market weight earlier than other breeds; hence serving the farmers with profit. The adaptability of Pattanam sheep towards the environmental conditions all over Tamil Nadu is found to be good. Hence, most of the farmers around Tamil Nadu prefer Pattanam sheep.

\section{Registration of Pattanam sheep}

Out of 11 sheep breeds, 10 sheep breeds are registered. Pattanam is the only sheep breed yet to be registered. In Tamil Nadu, the preference of farmers towards pattanam sheep is growing higher and higher. So it will be helpful for those farmers to obtain government schemes if this breed is registered. And so, it will be helpful for researchers to enhance genetic improvement in this breed and the economic status of those farmers can be improved. 


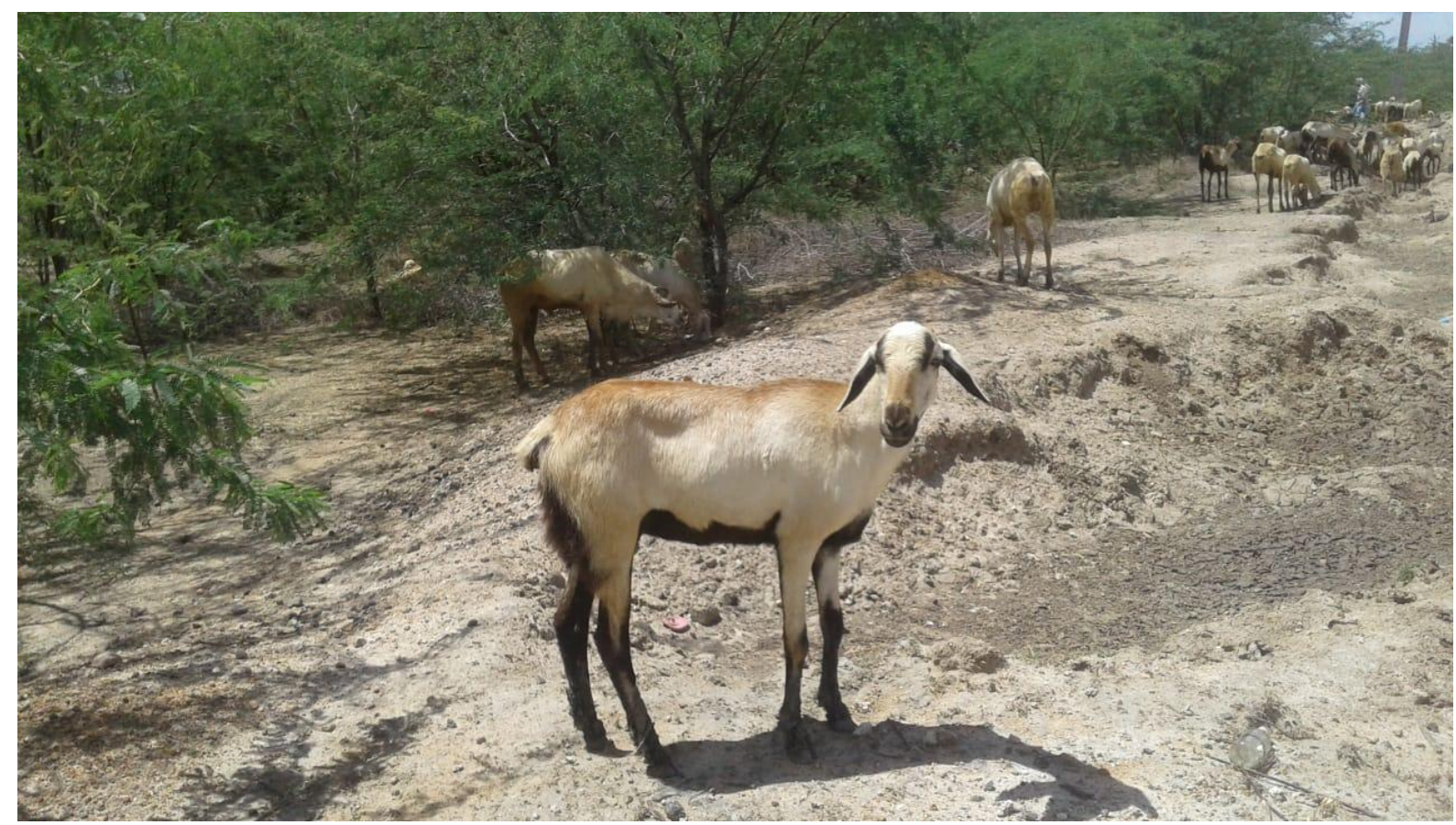

Fig.1 Ewe -Pattanam breed of sheep

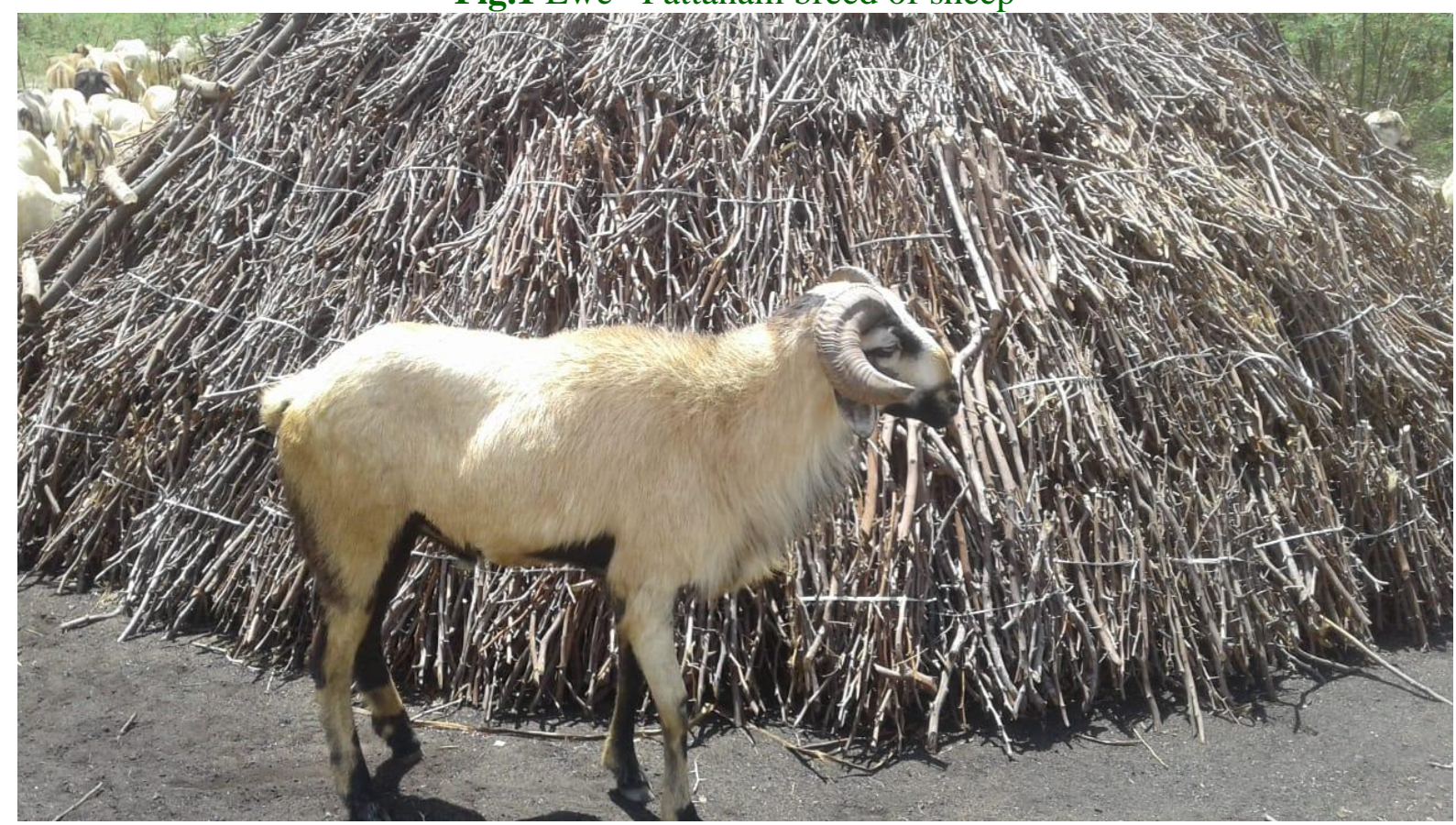

Fig.2 Ram - Pattanam breed of sheep

The present study shows that the colour, horn pattern and body confirmation are entirely different for both the breeds.Owing to the growing preferance among the farmers and larger size of the Pattanam sheep breed it would be advantageous to the farmers if the sheep breed is registered soon.

\section{References}

Raja, K.N., Singh, G., Jain, A and Luv Kumar.(2012). Ramnad White sheep phenotypic and genetic characterization. Indian J. Anim. Sci., 82(9):1082-1086.

Ramachandran, A., Thiruvenkadan, A.K., 
Kathiravan, P., Panneerselvam, S. and Elango, A. (2015). Microsatellite based phylogeny of Indian sheep breeds. Indian J. Anim. Sci.,1209-1214.

Ravimurugan, T and P.Devendran (2009). Body measurements and body weight of Ramnad White sheep. Indian J. Small Rumi., 15(2):266-267

Ravimurugan, T. (2017). Breed saviour's awards 2017. Livestock Keepers' Profile, 43-46.

Ravimurugan. T., A. K. Thiruvenkadan,
Krovvidi Sudhakar and S. Panneerselvam. (2012a). Sheep Genetic resources of southern TamilNadu, India. International Res. J. Agri. Sci.\& Soil Sci., 2(3):81-88.

Ravimurugan, T., A.K. Thiruvenkadan, KrovvidiSudhakar, A. Elango, S.Panneerselvam. (2012b). Breed characteristics of Pattanam sheep of Tamil Nadu, India. Animal Genetic Resources, 51, 99-104.

\section{How to cite this article:}

Ravimurugan. T. and Pavithra. P. 2020. Characterization and Evaluation of Pattanam Sheep of Tamilnadu. Int.J.Curr.Microbiol.App.Sci. 9(06): 2845-2849.

doi: https://doi.org/10.20546/ijcmas.2020.906.344 